\title{
IMPURITIES AND THEIR DISTRIBUTION IN TEMPERATE GLACIER ICE
}

\author{
By W. D. Harrison \\ (Geophysical Institute, University of Alaska, Fairbanks, Alaska 99701, U.S.A.)
}

and C. F. RAYMOND

(Geophysics Program, University of Washington, Seattle, Washington 98195, U.S.A.)

\begin{abstract}
Total impurity content of salt plus carbon dioxide was estimated as a function of grain size and depth in polycrystalline ice samples cored from a temperate glacier by measuring the electrical conductivity of the melt with air excluded. Conductivity decreased with increasing depth and grain size and ranged from $2.6 \times 10^{-5}$ to $0.4 \times \mathrm{IO}^{-5} \Omega^{-1} \mathrm{~m}^{-1}$ at $\mathrm{o}^{\circ} \mathrm{C}$. The conductivity of pure water at $\mathrm{O}^{\circ} \mathrm{C}$ is $0.1 \times 10^{-5} \Omega^{-1} \mathrm{~m}^{-1}$. Studies of the configuration of the three phases and of in situ temperature were also made. Thermodynamic constraints indicate that these impurities are probably concentrated as follows: about $5 \mathrm{~mol} \mathrm{~m}^{-3}$ in the liquid in the veins along three-grain intersections, roughly $\mathrm{I} \times 10^{-6} \mathrm{~mol} \mathrm{~m}^{-2}$ associated with grain-boundary area exclusive of veins, and about $0.7 \times 10^{-3} \mathrm{~mol} \mathrm{~m}^{-3}$ in volume exclusive of veins and grain boundaries. The last of these categories seems to account for most of the impurities in coarse ice (grain size about $20 \mathrm{~mm}$ ), but all three categories seem significant in fine ice (grain size about $2 \mathrm{~mm}$ ). Differences in bulk impurity content possibly indicate different histories of flushing by water.
\end{abstract}

RÉsumé Les impuretés dans la glace de glacier tempéré et leur distribution. Pour estimer le contenu total en sels et gaz carbonique en fonction de la dimension des grains et de la profondeur dans des échantillons de glace polycrystalline prélevés par forage dans un glacier tempéré, on a mesuré la conductivité électrique de l'eau de fusion, air exclu. La conductivité décroît avec la profondeur et la dimension des grains, et varie de $2,6 \times 10^{-5}$ à $0,4 \times 10^{-5} \Omega^{-1} \mathrm{~m}^{-1}$ à $0^{\circ} \mathrm{C}$. La conductivité de l'eau pure à $0^{\circ} \mathrm{C}$ est de $0,1 \times 10^{-5} \Omega^{-1} \mathrm{~m}^{-1}$. On a aussi étudié la configuration des trois phases et de la température "in situ". Des considérations thermodynamiques indiquent que ces impuretés sont probablement concentrées comme suit; environ $5 \mathrm{~mol} \mathrm{~m}^{-3}$ dans le liquide des vides aux intersections de trois grains, à peine $1 \times 10^{-6} \mathrm{~mol} \mathrm{~m}^{-2}$ le long de la surface des grains, à l'exclusion des vides, et environ $0,7 \times 10^{-3} \mathrm{~mol} \mathrm{~m}^{-3}$ dans le volume à l'exclusion des vides et des limites de grains. La dernière de ces catégories semble rendre compte de la plus grande partie des impuretés dans la glace à gros grains (éléments d'environ $20 \mathrm{~mm}$ ) mais les trois catégories sont importantes dans la glace fine (grains d'environ $2 \mathrm{~mm}$ de diamètre). Les différences entre les teneurs possibles en impuretés à l'unité de volume, révèlent des histoires différentes du lavage de la glace par l'eau.

Zusammenfassung. Verunreinigungen und ihre Verteilung im Eis temperierter Gletscher. Der Gesamtgehalt an Salz- und Kohlendioxyd-Verunreinigungen in polykristallinen Bohrproben aus einem temperierten Gletscher wurde als Funktion der Korngrösse und Tiefe durch Messung der Leitfähigkeit des luftfreien Schmelzwassers abgeschätzt. Die Leitfähigkeit nahm mit der Tiefe und Korngrösse ab und bewegte sich zwischen $2,6 \times 10^{-5}$ und $0,4 \times 10^{-5} \Omega^{-1} \mathrm{~m}^{-1}$ bei $0^{\circ} \mathrm{C}$. Die Leitfähigkeit reinen Wassers bei $0^{\circ} \mathrm{C}$ ist $0, \mathrm{I} \times 10^{-5}$ $\Omega^{-1} \mathrm{~m}^{-1}$. Auch die Konfiguration der drei Phasen und die in-situ-Temperatur wurden untersucht. Thermodynamische Einschränkungen weisen auf folgende wahrscheinliche Verteilung dieser Verunreinigungen hin: etwa $5 \mathrm{~mol} \mathrm{~m}^{-3}$ in flüssiger Phase in den Adern längs dreifacher Korngrenzen, ungefähr $\mathrm{I} \times \mathrm{IO}^{-6} \mathrm{~mol} \mathrm{~m}^{-2}$ in Korngrenzgebieten ausschliesslich der Adern und etwa $0,7 \times 10^{-3} \mathrm{~mol} \mathrm{~m}^{-3}$ in Räumen ausserhalb der Adern und Korngrenzen. Die letzte dieser Kategorien scheint für die meisten Verunreinigungen in grobem Eis (Korngrösse etwa $20 \mathrm{~mm}$ ) zuzutreffen, aber alle drei Kategorien sind bezeichnend für feines Eis (Korngrösse etwa $2 \mathrm{~mm}$ ). Unterschiede im Gesamtgehalt an Verunreinigungen deuten möglicherweise auf unterschiedliche Vorbearbeitung durch Wasserspülung hin.

\section{Introduction}

Many studies have been made of the impurities in glacier ice, and from many different points of view. Examples are the study of impurities to examine the record of man-made pollution, the use of impurities and isotopes as tracers giving useful information about the origin of the ice, and the effect of impurities on the mechanical and electrical properties of ice. The approach of this work is somewhat similar to the last of these, in that it focuses on the physical chemistry of temperate glacier ice, and especially on the distribution of impurities among the three phases and the grain boundaries. Examples of a somewhat similar approach are Renaud (1949), who showed that impurities tend to be concentrated at grain boundaries, and Paren and Walker (197I), who considered some effects of the limited solubility of impurities in the solid phase. Considerable information about the incorporation of impurities 
into laboratory grown ice also exists (Maeno, 1973, for example). The chemistry of temperate ice is of special interest because of its relation to the thermal properties and the hydrology of the ice.

Measurements were made in the field on core samples from Blue Glacier, a temperate glacier on Mt Olympus, Washington State, U.S.A. The coring was done in August 1972 at a site slightly below the usual late-summer snow line. Further information on the field setting, the texture of the ice, and the configuration of the liquid and gas phases is given by Raymond and Harrison (1975). As part of the work, deep temperature measurements were made at a nearby site (Harrison, I975[b]). A study of the electrical conductivity of melted samples and its relation to these other studies is described here.

\section{EXPERIMENTAL METHODS AND RESUlts}

Cores $150 \mathrm{~mm}$ in diameter were obtained with a thermal core drill, as described by Raymond and Harrison (1975). The core was removed from the fibre-glass core barrel with polyethylene gloves and carried to a nearby snow cave where a length of about $150 \mathrm{~mm}$ was cut out with a few strokes of a stainless-steel ice pick, rinsed with the melt of the previous sample, and placed in a "Pyrex" glass beaker. The beaker was placed in a small vacuum chamber and the air pumped out, after which heat was applied and the sample melted at the triple point. A conductivity cell with platinized electrodes, mounted inside the lid of the vacuum chamber, was then immediately inserted into the melt with the help of a sliding vacuum seal, and electrical conductivity was measured using a $400 \mathrm{~Hz}$ square-wave signal. A slow pumping rate was continuously maintained during the melting and the conductivity measurement. A tendency for the measured conductivity to increase slowly with time was noted, although the original conductivity could be recovered by lifting the cell out of the melt and replacing it. Because of this instability, the estimated accuracy is roughly $30 \%$. It is necessary to do this type of measurement with air excluded because the electrical conductivity of water equilibrated with atmospheric carbon dioxide (about $6 \times 1 \mathrm{I}^{-5} \Omega^{-1} \mathrm{~m}^{-1}$ at $\mathrm{o}^{\circ} \mathrm{C}$ ) is considerably greater than that of any of the samples measured, and the carbon dioxide, once dissolved, is not easily removed.

It is known from studies of cold glaciers that core samples can be contaminated during drilling, both in dry holes and in those into which anti-freeze or other liquids have been put (Murozumi and others, I969; Ragone and Finelli, 1972). The situation in our experiment was somewhat different, in that the core hole contained water from the glacier, probably of very high purity. Also, the heat dissipated along the core barrel in order to transmit high current to the heater tended to help remove impurities by melting roughly io $\mathrm{mm}$ from the surface of the core. Nevertheless, the possibility of some contamination during drilling, handling, or melting cannot be excluded, even though the samples were found to be extremely pure. An interesting possibility is the very opposite: that impurities may have been lost by liquid motion through the veins lying along the three-grain intersections (Nye and Frank, 1973). This is likely to be unimportant because (I) much of the liquid forced out by excess gas pressure in bubbles probably tends to be trapped by intervening bubbles, and (2) gravity drainage through the small-diameter veins is small on the time scale of about 5 min between core recovery and placement of samples in the beaker. More information is given by Raymond and Harrison (1975).

The conductivity measurements were accompanied by the determination of grain size, which is defined to be the reciprocal of the number of grain-boundary intercepts per unit length of randomly oriented lines (McLean, I957, p. I12), as measured on thin sections and etched surfaces. Each grain-size sample was cut perpendicular to the core axis, and was usually located within about $50 \mathrm{~mm}$ of the conductivity sample. Since the grain size was probably not always the same in both samples, some uncertainty in the grain size of the 
conductivity sample exists. Other related textural studies are described by Raymond and Harrison (1975).

The impurity and textural measurements are summarized in Figure I, which illustrates the tendency for increasing grain size and decreasing conductivity with depth.

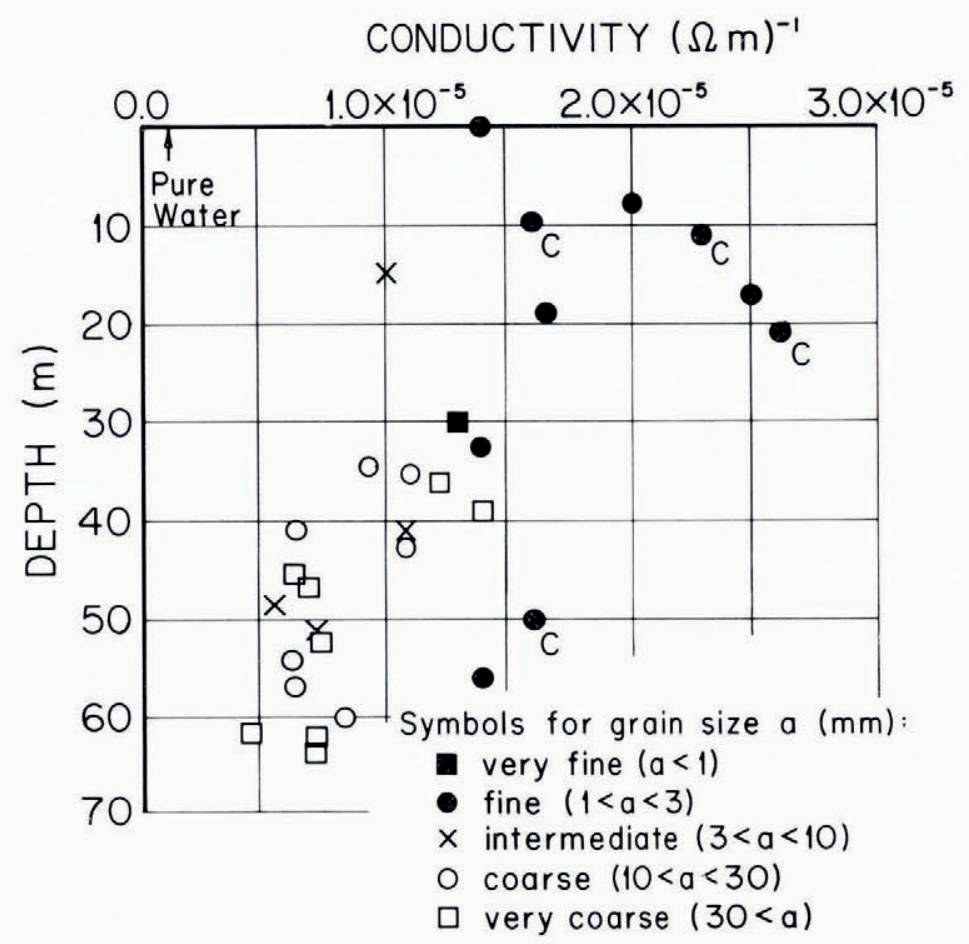

Fig. I. Dependence of $o^{\circ} \mathrm{C}$ electrical conductivity of melted samples upon grain size and depth. All samples were bubbly except those marked with the symbol $C$. The sample at zero depth consisted of snow. The conductivity of pure water is indicated at the top of the figure.

\section{Discussion}

\section{I. Impurity content and dependence upon grain size}

Figure 1 shows that there is a decrease in electrical conductivity of the melt with increasing grain size. Although there is considerable scatter, at least some of it is probably due to uncertainty in the grain size of the conductivity samples, and it therefore seems reasonable to attempt to assign representative values of conductivity to fine and coarse ice. As we shall see, this permits a discussion of the location of the impurities. A conductivity of $2 \times \mathrm{IO}^{-5} \Omega^{-1} \mathrm{~m}^{-1}$ is fairly representative of fine ice (grain size between I and $3 \mathrm{~mm}$ ) and a conductivity of about $0.7 \times 10^{-5} \Omega^{-1} \mathrm{~m}^{-1}$, of coarse and very coarse ice (grain size greater than $\mathrm{Io} \mathrm{mm}$ ).

Since no chemical analysis was performed, the composition of the impurities contributing to the conductivity is uncertain. It is possible that the impurities are mostly salts, but the contribution of in situ carbon dioxide needs to be considered also. (The experimental technique was designed to avoid contamination by external sources of carbon dioxide.) Some laboratory experiments carried out before the field work indicated that little carbon dioxide, once dissolved in the melt, would be removed by the time that the conductivity was measured. Whether or not any carbon dioxide present in situ was ever dissolved in the melt, or merely 
pumped away, is not certain. But since most of the melting took place at the sample bottom, where a gas-filled cavity was usually seen to form, it seems likely that contact with the liquid was maintained long enough for most of the carbon dioxide to be dissolved. The carbon dioxide content of temperate glacier ice has been studied by others. Weiss and others (1972), for example, determined by direct gas analysis carbon dioxide contents in the range $0.5 \times \mathrm{IO}^{-7}$ to $7 \times 10^{-7} \mathrm{~m}^{3}$ at s.t.p. per kilogram of ice. This would correspond to a melt conductivity range of about $1.5 \times \mathrm{IO}^{-5}$ to $7 \times \mathrm{IO}^{-5} \Omega^{-1} \mathrm{~m}^{-1}$ (see Appendix), which is to be compared with our measured range of $0.4 \times 10^{-5}$ to $2.6 \times 10^{-5} \Omega^{-1} \mathrm{~m}^{-1}$. Although it may be possible that their extraction technique also removed carbon dioxide from carbonate dust particles, their results certainly indicate that carbon dioxide in the ice itself may be important.

If the impurities are mostly salts, the electrical conductivity $\kappa$ can be used to estimate their total concentration (see Appendix). At $0^{\circ} \mathrm{C}$ the concentration $C$ in equivalents* per unit volume and the conductivity $\kappa$ are related by

$$
C \approx \nu\left(\kappa-\kappa_{0}\right)
$$

where $\nu=\mathrm{I} 5 \mathrm{O}$ equivalent $\Omega \mathrm{m}^{-2}$ and $\kappa_{0}=0 . \mathrm{I} \times \mathrm{IO}^{-5} \Omega^{-1} \mathrm{~m}^{-1}$ is the conductivity of pure water. Equation (I) applies to the concentration of the melt. The concentration of the bulk ice is smaller by a factor equal to the density ratio of about o.9o. If carbon dioxide is also present, it is possible to interpret Equation (I) as giving an estimate of the total concentration of salt plus carbon dioxide, because over the concentration range of interest the dependence of concentration on conductivity is roughly the same for both substances. The approximation involved is discussed in the Appendix.

With this interpretation and its limitations in mind, the representative contents of salt plus carbon dioxide of the fine and coarse ice are about $3 \times 1 \mathrm{IO}^{-3}$ and $0.8 \times \mathrm{IO}^{-3}$ equivalent $\mathrm{m}^{-3}$ respectively. The concentration of dissolved molecules in $\mathrm{mol} \mathrm{m}^{-3}$ should be about the same, but the particle concentrations should be about twice as large because of dissociation (see Appendix).

\subsection{Distribution of impurities}

The higher impurity content of the fine ice, together with additional information about texture, in situ temperature and liquid-water content (Harrison, I975[b]; Raymond and Harrison, 1975; Raymond, I976), makes it possible to attempt a semi-quantitative discussion of impurity distribution. The method and results are summarized in Table I and discussed in the following paragraphs.

The gas phase is considered first. The lack of any obvious difference in conductivity between clear and bubbly ice (Fig. I) suggests that the contribution from carbon dioxide in gas bubbles is small. This contribution would have been significant in the deep ice, about $\mathrm{I} .2 \times \mathrm{IO}^{-5} \Omega^{-1} \mathrm{~m}^{-1}$, if the bubbles had the carbon dioxide content of air at a pressure equal to the overburden pressure, the density were $0.90 \mathrm{Mg} \mathrm{m}^{-3}$, and all the carbon dioxide were dissolved on melting. It may be relevant that other measurements (see Weiss and others, 1972) seem to indicate that little of the carbon dioxide in temperate glacier ice is in the gas phase.

Some indication of the in situ liquid-phase impurity content is given by measurements discussed elsewhere (Harrison, I975[b]; Raymond and Harrison, I975; Raymond, I976). In the shallow fine ice a temperature lowering of about 0.020 deg implies an impurity concentration of about $5.5 \mathrm{~mol} \mathrm{~m}^{-3}$ in the liquid contained in the veins at the three-grain intersections assuming the impurity molecules are dissociated. $\dagger$ Since the veins have a cross-sectional area of roughly $\mathrm{I} \times \mathrm{IO}^{-10} \mathrm{~m}^{2}$, the impurity concentration per unit length of

\footnotetext{
* In this paper gram equivalent and molecular weights are used.

$\dagger$ It is unlikely that much of this temperature lowering is due to pressure, at least if the vein pressure is about the same as the ice mean stress. A very small vertical strain-rate (Harrison, 1975[a]) provides evidence that the ice mean stress is about the same as the overburden pressure.
} 
vein is roughly $5.5 \times 10^{-10} \mathrm{~mol} \mathrm{~m}-1$, which should probably be rounded off to $\mathrm{I} \times \mathrm{IO}^{-9} \mathrm{~mol} \mathrm{~m}^{-1}$ considering the uncertainties. The total length of vein per unit bulk volume of fine ice is about $\mathrm{I} \times 10^{6} \mathrm{~m}^{-2}$, implying a bulk impurity contribution from the veins in the fine ice of roughly $\mathrm{I} \times \mathrm{IO}^{-3} \mathrm{~mol} \mathrm{~m}^{-3}$. This is probably significantly less than the total bulk impurity concentration of $3 \times \mathrm{IO}^{-3} \mathrm{~mol} \mathrm{~m}^{-3}$ estimated from the melt conductivity, although some doubt exists because of the large uncertainty in vein size (Raymond and Harrison, 1975). It may also be worth noting that the in situ vein liquid concentration, higher than in most tap water, may be high enough that dissociation is less than in the melt. In the coarse ice the total vein impurity content is very small compared with the total content of salt plus carbon dioxide, because so few veins are present. If the vein impurities are predominantly salt and carbon dioxide, subtraction implies that their bulk particle concentrations outside the veins are about $2 \times 10^{-3} \mathrm{~mol} \mathrm{~m}^{-3}$ in fine ice, and $0.8 \times 10^{-3} \mathrm{~mol} \mathrm{~m}^{-3}$ in coarse ice. Since the total vein impurity content is fairly low in fine ice, and negligible in coarse ice, these values change little even if the vein impurities are not predominantly salt and carbon dioxide. This is especially possible in the deep ice where pressure is large enough that air dissolved in the vein liquid may make a substantial contribution to the temperature lowering.

Outside the veins some of the impurities are associated with grain-boundary area, and the rest with the interior of crystals. The concentrations at these locations can be found using the above bulk concentrations outside the veins in fine and coarse ice, if the grain-boundary area per unit volume $\sigma$ can be evaluated. This is given by

$$
\sigma=2 / a
$$

where $a$ is the grain size (Smith and Guttman, I953). More details are found in Table I. The assumption that these concentrations are independent of texture is necessary, and it may be reasonable, basically because the temperature depression by impurities seems to be about the same in all the ice sampled (Harrison, I975[b]; Raymond and Harrison, 1975). This implies that all the ice is in contact with liquid of about the same impurity concentration, although the composition may not be constant over the entire depth sampled. At any rate, the results are $\mathrm{I} \times \mathrm{IO}^{-6} \mathrm{~mol} \mathrm{~m}^{-2}$ of grain-boundary area exclusive of veins, and $0.7 \times \mathrm{IO}^{-3}$ $\mathrm{mol} \mathrm{m} \mathrm{m}^{-3}$ of volume exclusive of grain boundaries and veins. The first of these values should probably be considered an order-of-magnitude estimate, since it is sensitive to uncertainty in vein size, which, as already noted, is large. The second is sensitive to uncertainty in grain size, among other things, and could easily be in error by a factor of perhaps 2 or 3 . The grainboundary area concentration might include impurities in liquid-filled lenses on the grain

TABLE I. IMPURITY DISTRIBUTION IN POLYCRYSTALLINE TEMPERATE GLACIER ICE AS FOUND FROM

$$
C=l C_{l}+\sigma C_{\sigma}+C_{v}
$$

WHERE THE SYMBOLS ARE DEFINED IN THE FIRST COLUMN

Input values

\footnotetext{
$C$ (total concentration per unit bulk volume of ice)

$C_{l} \quad$ (concentration per unit length of vein)

$l$ (vein length per unit volume)

$\sigma \quad$ (grain boundary area per unit volume)
}

\section{Calculated values}

$C_{\sigma}$ (concentration per unit area of grain boundary exclusive of veins)

$C_{v}$ (concentration per unit volume exclusive of grain boundaries and veins)

\section{Impurity totals}

$l C_{l} \quad$ (in veins)

$\sigma C_{\sigma}$ (in grain boundary area exclusive of veins)

$C_{v}$ (in volume exclusive of grain boundaries and veins)

$$
\begin{aligned}
& \text { Fine ice Coarse ice } \\
& \text { (grain size } \approx 2 \mathrm{~mm}) \quad(\text { grain size } \approx 20 \mathrm{~mm} \text { ) } \\
& 3 \times 10^{-3} \mathrm{~mol} \mathrm{~m}^{-3} \quad 0.8 \times \mathrm{IO}^{-3} \\
& \mathrm{I} \times \mathrm{IO}^{-9} \mathrm{~mol} \mathrm{~m}^{-\mathrm{r}} \\
& \mathrm{I} \times \mathrm{IO}^{6} \mathrm{~m}^{-2} \quad \mathrm{I} \times \mathrm{IO}^{4} \\
& \mathrm{I} \times 10^{3} \mathrm{~m}^{-1} \quad \mathrm{I} \times \mathrm{IO}^{2}
\end{aligned}
$$

$$
\mathrm{I} \times \mathrm{IO}^{-6} \mathrm{~mol} \mathrm{~m}^{-2}
$$$$
0.7 \times 10^{-3} \mathrm{~mol} \mathrm{~m}^{-3}
$$

$$
\begin{array}{cc}
\mathrm{I} \times \mathrm{IO}^{-3} \mathrm{~mol} \mathrm{~m}^{-3} & \mathrm{I} \times \mathrm{IO}^{-5} \\
\mathrm{I} \times \mathrm{IO}^{-3} \mathrm{~mol} \mathrm{~m}^{-3} & 0 . \mathrm{I} \times \mathrm{IO}^{-3} \\
0.7 \times \mathrm{IO}^{-3} \mathrm{~mol} \mathrm{~m}^{-3}
\end{array}
$$


boundaries (Nye and Mae, I972); whether or not they were actually present in situ is not certain (Raymond and Harrison, 1975). In any case these grain-boundary impurities should be distributed within a finite volume along the grain boundaries. The concentration per unit volume exclusive of grain boundaries and veins is about the same as the total concentration in the coarse ice. This would be the concentration of salt and carbon dioxide dissolved in the ice lattice, as long as significant amounts of water outside veins and grain boundaries was not present in situ. Observations are consistent with this being so (Raymond and Harrison, I975; Raymond, I976), but it is not certain.

This value of $0.7 \times \mathrm{IO}^{-3} \mathrm{~mol} \mathrm{~m}^{-3}$, possibly the lattice impurity content, is 50 or more times less than the lattice solubility found in the laboratory for $\mathrm{HCl}$ at about the same temperature (Seidensticker, I972), although some disagreement in the laboratory experiment exists. ${ }^{*}$ If the Blue Glacier salt and carbon dioxide impurities had the same lattice solubility as this value for $\mathrm{HCl}$, under equilibrium conditions they could not account for the observed presence of the liquid phase (Raymond and Harrison, 1975). This would imply that the major impurities in the liquid phase are not salt and carbon dioxide. But it is equally plausible that, whatever the actual composition of what we have called salt and carbon dioxide impurities, the value estimated here does represent their solubility at the in situ temperature.

The value of $0.7 \times \mathrm{IO}^{-3} \mathrm{~mol} \mathrm{~m}-3$ is probably also significantly less than the $2 \times 10^{-3} \mathrm{~mol} \mathrm{~m}^{-3}$ estimated for the solubility limit of sea salts in cold ice by Paren and Walker (197I). Below the solubility limit, or saturation concentration, one would expect the solid concentration of impurities to decrease with increasing temperature, just as the liquid concentration does, because of equilibrium between the impurities in the two phases. Our value, which as already noted is about the same as the total concentration in coarse ice, is also slightly less, although not necessarily significantly so, than the total concentration of sea salts in cold ice from interior Greenland and Antarctica found by Murozumi and others ( 1969 ) to be $1.0 \times 10^{-3} \mathrm{~mol} \mathrm{~m}^{-3}$ and $\mathrm{I} .7 \times \mathrm{IO}^{-3} \mathrm{~mol} \mathrm{~m}^{-3}$, respectively. They did not measure the textural dependence of the concentration. Considering that our value could contain a substantial contribution from carbon dioxide, and that the possibility of some sample contamination has not been completely ruled out, it seems that coarse Blue Glacier ice may contain substantially less salt than ice from the polar regions, even though it is located within $60 \mathrm{~km}$ of the Pacific Ocean.

\subsection{History of the ice}

At the location of the core hole, the ice above about $30 \mathrm{~m}$ depth is mostly fine, and below it is mostly coarse. Therefore the textural dependence of the impurity content also corresponds to a much lower bulk impurity content of the deep ice than of the shallow ice. This indicates either a difference in impurity content associated with the original deposition, or different histories of flushing by water motion, perhaps when what is now ice was snow or firn. Temperature measurements (Harrison, 1975[b]) seem to indicate that the present flushing of impurities from the ice now located at the site of the core hole is very slow (Raymond and Harrison, 1975).

\section{Summary}

A somewhat crude physico-chemical picture of temperate glacier ice has emerged from simultaneous measurement of temperature, texture, and liquid and impurity contents. The approach has been essentially descriptive in that we have attempted to learn what conditions are at one site in a temperate glacier, but have not seriously addressed the interesting question of what determines them.

* The HCl lattice solubility found by Krishnan and Salomon (1969) is much lower, but pending clarification of a number of inconsistencies in their paper (private communication between Harrison and Salomon), we prefer to use Seidenstickers' value. 
Although the bulk impurity concentration of the ice studied is extremely low, the concentration in the in situ liquid phase is higher than in most tap water. The impurities have significant effects on temperature and thermal properties, and on processes such as regelation (Drake and Shreve, I973) and the refreezing of bore holes (Harrison, I972). The effect on glacier hydrology, basal sliding, and possibly mechanical properties may also be significant.

\section{Acknowledgements}

We are grateful for assistance in the field by Professor E. R. LaChapelle, Suzanne Cummings Brown and Loren Chatzen, and for comments by several colleagues. The U.S. National Park Service gave permission for the work, and principal support was from the National Science Foundation under grants GA-28554, GA-36039, and GA-36o4o. One of us (W.D.H.) also acknowledges support from State of Alaska funds.

\section{REFERENGES}

Drake, L. D., and Shreve, R. L. 1973. Pressure melting and regelation of ice by round wires. Proceedings of the Royal Society of London, Ser. A, Vol. 332 , No. 1588 , p. $51-83$.

Harrison, W. D. 1972. Temperature of a temperate glacier. Fournal of Glaciology, Vol. 1 1, No. 61, p. $15-29$.

Harrison, W. D. 1975 [a]. A measurement of surface-perpendicular strain-rate in a glacier. Fournal of Glaciology, Vol. 14, No. 70, p. $31-37$.

Harrison, W. D. 1975 [b]. Temperature measurements in a temperate glacier. Fournal of Glaciology, Vol. 14, No. 7o, p. $23-30$.

Krishnan, P. N., and Salomon, R. E. 1969. Solubility of hydrogen chloride in ice. Fournal of Physical Chemistry, Vol. 73 , No. 8, p. $2680-83$.

McLean, D. 1957. Grain boundaries in metals. Oxford, Clarendon Press.

Maeno, N. I973. Studies of the dielectric properties of ice grown from KCl solution. Contributions from the Institute of Low Temperature Science (Sapporo), Ser. A, No. 25, p. I-47.

Murozumi, M., and others. I969. Chemical concentrations of pollutant lead aerosols, terrestrial dusts and sea salts in Greenland and Antarctic snow strata, [by] M. Murozumi, T. J. Chow and C. Patterson. Geochimica et Cosmochimica Acta, Vol. 33 , No. 1o, p. 1247-94.

Nye, J. F., and Frank, F. C. 1973. Hydrology of the intergranular veins in a temperate glacier. Union Géodésique et Géophysique Internationale. Association Internationale d'Hydrologie Scientifique. Commission de Neiges et Glaces. Symposium on the Hydrology of Glaciers, Cambridge, 7-13 September 1969, p. $157-61$.

Nye, J. F., and Mae, S. 1972. The effect of non-hydrostatic stress on intergranular water veins and lenses in ice. fournal of Glaciology, Vol. 11 , No. 61, p. 81-101.

Paren, J. G., and Walker, J. C. F. 1971. Influence of limited solubility on the electrical and mechanical properties of ice. Nature, Physical Science, Vol. 230, No. 12, p. 77-79.

Ragone, S. E., and Finelli, R. 1972. Procedures for removing surface contaminants from deep ice cores. U.S. Cold Regions Research and Engineering Laboratory. Special Report 167, p. I-7.

Raymond, C. F. 1976. Some thermal effects of bubbles in temperate glacier ice. Fournal of Glaciology, Vol. i6, No. 74 , p. $159-7$.

Raymond, C. F., and Harrison, W. D. I975. Some observations on the behavior of the liquid and gas phases in temperate glacier ice. Fournal of Glaciology, Vol. 14, No. 71, p. 213-33.

Renaud, A. 1949. A contribution to the study of the glacier grain. Fournal of Glaciology, Vol. 1, No. 6, p. $320-24$.

Seidensticker, R. G. 1972. Partitioning of $\mathrm{HCl}$ in the water-ice system. Fournal of Chemical Physics, Vol. 56 , No. 6, p. $2853-57$.

Smith, C. S., and Guttman, L. 1953. Measurement of internal boundaries in three-dimensional structures by random sectioning. Fournal of Metals, Vol. 5, No. I, p. 8I-87.

Weiss, R. F., and others. 1972 . Compositional variations of gases in temperate glaciers, [by] R. F. Weiss, P. Bucher, H. Oeschger and H. Craig. Earth and Planetary Science Letters, Vol. 16, No. 2, p. $178-84$. 


\section{APPENDIX}

THE relation between concentration of electrolytic solutions and electrical conductivity is found in all textbooks on physical chemistry. Here we are interested in dilute aqueous solutions. Let $\Lambda^{0}$ be the equivalent conductivity of the solute at infinite dilution, when dissociation is complete. Then solute concentration $C$, expressed as equivalents per unit volume, is related to conductivity $\kappa$ by

$$
C=\frac{\kappa}{\alpha \Lambda^{0}}
$$

where $\alpha$ is the degree of dissociation. For a strong electrolyte the dissociation is essentially complete and $\alpha=\mathbf{I}$. For a weak electrolyte $\alpha$ depends upon concentration, even though the solution is dilute, and is found from

$$
K=\frac{C \alpha^{2}}{\mathrm{I}-\alpha}
$$

where $K$ is the dissociation constant. Combination of Equations (A-I) and (A-2) gives

$$
C=\frac{\kappa}{\Lambda^{0}}+\frac{1}{K}\left(\frac{\kappa}{\Lambda^{0}}\right)^{2}
$$

For most salts, dissociation is complete at the extremely low concentrations of interest, so $\alpha=1$. Since the equivalent conductivities of most salts are very similar, Equation (A-I) will give an estimate of the total number of equivalents of salt per unit volume when $\Lambda^{0}=6.7 \times \mathrm{IO}^{-3}$ equivalent $\mathrm{t}^{-1} \Omega^{-1} \mathrm{~m}^{2}$, which is the value for $\mathrm{NaCl}$ at $\mathrm{o}^{\circ} \mathrm{C}$. Concentrations of acids and bases would be over-estimated because the equivalent conductivities of the $\mathrm{H}^{+}$and $\mathrm{OH}^{-}$ions are anomalously high. Because some of the concentrations of interest are so low, it is worthwhile to subtract from the conductivity in Equation $(\mathrm{A}-\mathrm{I})$ the contribution $\kappa_{0}$ from the dissociation of water at $0^{\circ} \mathrm{C}$. Then

$$
C=\nu\left(\kappa-\kappa_{0}\right)
$$

where $\nu=150$ equivalent $\Omega \mathrm{m}^{-2}$ and $\kappa_{0}=0 . \mathrm{I} \times \mathrm{IO}^{-5} \Omega^{-1} \mathrm{~m}^{-1}$.

If the solute is predominantly dissolved carbon dioxide, Equation (A-3) applies with $\Lambda^{0}=2.65 \times 10^{-2}$ equivalent ${ }^{-1} \Omega^{-1} \mathrm{~m}^{2}$ and $K=2.6 \times 10^{-4}$ equivalent $\mathrm{m}^{-3}$. Then

$$
C=\nu_{1} \kappa+\nu_{2} \kappa^{2}
$$

where $v_{1}=38$ equivalent $\Omega \mathrm{m}^{-2}$, and $\nu_{2}=5.6 \times 10^{6}$ equivalent $\Omega^{2} \mathrm{~m}^{-1}$. This refers to the total carbon dioxide that is dissolved and not to just the portions hydrated and dissociated. Although extremely low, the conductivities of interest are sufficiently high that $(\mathrm{I})$ the second dissociation of carbon dioxide, which would complicate this picture, can be neglected, and (2) no water correction is necessary, essentially because $\mathrm{pH}$ is controlled by the carbon dioxide.

For a dilute solution containing both salt and carbon dioxide, the dependence of conductivity on the concentrations can be found by solving Equations (A-4) and (A-5) for the individual contributions of each substance to the conductivity, and adding. Although the result is slightly complicated, a simple conductivity-concentration interpretation is still possible, because over the limited conductivity range of interest, say from $0.5 \times 10^{-5}$ to $2.0 \times 1 O^{-5} \Omega^{-1} \mathrm{~m}^{-1}$, the conductivity-concentration dependence is roughly the same for both substances. (This is easily seen from plots of Equations (A-4) and (A-5).) As a result, Equation (A-4) (or (A-5)) can be interpreted as giving the total concentration of salt plus carbon dioxide when both are present. The associated error is negligible at the upper end of the concentration range compared with other uncertainties. The worst case occurs at the lower end where the concentration of a solution containing predominantly carbon dioxide would be overestimated by a factor of about two when Equation (A-4) for salt is used.

Concentration units other than equivalents per unit volume are of interest. In the case of salt, the concentration in moles is the same as that in equivalents, but the concentration of the total number of particles is twice as large because of dissociation. This applies if all valences are unity. If divalent species are abundant, these other concentrations could be over-estimated by a factor of two. In the case of carbon dioxide the concentration in moles is also the same as the concentration in equivalents, but since not every dissolved carbon dioxide molecule gives rise to two ions, the particle concentration is only larger by the factor $(1+\alpha)$, where $\alpha$ is determined by Equations (A-2) and (A-3). This factor varies from 1.6 to 1.3 over the conductivity range $0.5 \times 10^{-5}$ to $2 \times 10^{-5}$ $\Omega^{-1} \mathrm{~m}^{-1}$.

With the differences between salt and carbon dioxide in mind, Equation (A-4) for salt can be interpreted as giving an estimate of the total salt plus carbon dioxide concentration in equivalents, and the other concentration units estimated using the rules for salt.

\section{DISGUSSION}

J. F. NyE: Have you any comment on the question of whether the impurities in the interior of the grains may be concentrated on dislocations? If they were, could they cause local melting of the dislocation cores? This would be in addition to the possible effect of the very high shear stresses at a dislocation in causing stress melting of the dislocation core (see discussion on Weertman's paper at the Ottawa conference (Nye, I973).) 
J. W. GLEN (Reply to Nye) : If most of the dissolved salts were in dislocations, then, presumably, the solubility of the solid would depend on dislocation density, and there would be no proper $k$ value for solution of salts in ice. In fact people have found difficulties in measuring $k$ values, so perhaps the evidence is ambiguous, but I know of no suggestion that dissolution is easier in deformed ice. The question is complicated by the fact that freezing saline water does give a much higher dislocation density. Whether you could test this by X-ray topography or electron microscopy I rather doubt. X-ray topography certainly "sees" dislocations, but I doubt if it could "see" impurities or a molten tunnel along the core. Electron microscopy itself tends to damage and melt ice and could itself produce a molten tube.

Finally, a question. Would it not be desirable to use specific ion electrodes, perhaps on the melt from outsides of crystals preferentially, to see if the impurities are chloride or carbonate? W. D. Harrison: Glen's answer seems more relevant to Nye's question than our data are. With regard to Glen's question, it would obviously be extremely desirable to obtain both specific ion and dissolved $\mathrm{CO}_{2}$ data. Even then, the conductivity data are useful because they give a rough idea of total ion content, which is most relevant from a strictly thermodynamic point of view.

\section{REFERENCE}

Nye, J. F. 1973. Discussion. (In Whalley, E., and others, ed. Physics and chemistry of ice: papers presented at the Symposium on the Physics and Chemistry of Ice, held in Ottawa, Canada, 14-18 August 1972. Edited by E. Whalley, S. F. Jones, L. W. Gold. Ottawa, Royal Society of Canada, p. 395.) 